\title{
The Journey of Poly(ethylene glycol) in Living Cells
}

6 Transformative Molecules, Shanghai Jiao Tong University, 800 Dongchuan Road,

* Corresponding authors.

13 E-mail addresses: xyzhu@sjtu.edu.cn (X. Zhu); yuesu@sjtu.edu.cn (Y. Su) 
17 Liquid chromatography-mass spectrometry (LC-MS) was performed on a Water 18 ACQUITY UPLC system equipped with a binary solvent delivery manager and a 19 sample manager coupled to a Waters Q-TOF Premier Mass Spectrometer equipped with 20 an electrospray interface (Waters Corporation, Milford, MA). The column is equipped 21 with Acquity UPLC® $\mathrm{C} 18(1.7 \mu \mathrm{m}, 2.1 \times 100 \mathrm{~mm}$, waters $)$ and the mobile phase was 22 formic acid/water (A phase) and famic acid/ acetonitrile (B phase), gradient elution. ${ }^{1} \mathrm{H}$ 23 nuclear magnetic resonance spectroscopy ( ${ }^{1} \mathrm{H}$ NMR) of PEG-PPa and PEG-RB was 24 characterized by $400 \mathrm{MHz}$ spectrometer (Varian) and $700 \mathrm{MHz}$ spectrometer (AVANCE NEO 700MHz, Bruker), respectively. Fluorescent spectra and quantum yield of the fluorescent molecules were employed using steady state and time-resolved photoluminescence spectroscopy (FLS1000). The infrared spectroscopy (IR) was processed on the instrument of FT-IR spectrometer (Nicolet 6700, Thermo Scientific).

29 Synthesis of PEG-PPa and PEG-RB. $1.1 \mathrm{mmol} \mathrm{PPa}$ was dissolved in $3 \mathrm{~mL}$ 30 dichloromethane (DCM) and $3.33 \mathrm{mg}$ (1.5 mmol) of 1-(3-dimethylaminopropyl)-331 ethylcarbodiimide hydrochloride (EDC.HCl), $2 \mathrm{mg}(1.5 \mathrm{mmol})$ of $\mathrm{N}$ 32 hydroxysuccinimide (NHS) and $2.42 \mu \mathrm{L}(1.5 \mathrm{mmol})$ of triethylamine (TEA) were added 33 to this solution. After the solution was stirred for $6 \mathrm{~h}, 5 \mathrm{mg}(1 \mathrm{mmol})$ of $\mathrm{PEG}-\mathrm{NH}_{2}$ in $34100 \mu \mathrm{L}$ of $N, N$-dimethylformamide (DMF) was added. The reaction was kept for $24 \mathrm{~h}$ 35 under stirring at room temperature. The crude product was processed by dialysis 

a freeze-dryer system (Martin Christ, $\alpha 1-4$, Germany). Yield: 60\%. ${ }^{1} \mathrm{H}$ NMR (400 MHz, $\left.\mathrm{CDCl}_{3}\right) \delta 9.51(\mathrm{~s}, 1 \mathrm{H}), 9.40(\mathrm{~s}, 1 \mathrm{H}), 8.56(\mathrm{~s}, 1 \mathrm{H}), 8.02(\mathrm{~s}, 1 \mathrm{H}), 6.57(\mathrm{~m}, 2 \mathrm{H}), 6.29(\mathrm{~d}, J$ $=20 \mathrm{~Hz}, 1 \mathrm{H}), 6.19(\mathrm{~s}, 1 \mathrm{H}), 5.27(\mathrm{~d}, J=20.0 \mathrm{~Hz}, 1 \mathrm{H}), 5.13(\mathrm{~s}, 1 \mathrm{H}), 3.63(\mathrm{~s}, 251 \mathrm{H}), 3.46$ $\mathrm{Hz}, 1 \mathrm{H}), 1.70$ (s, 1H), 1.24 (s, 2H) ppm. NMR (700 MHz, $\left.\mathrm{D}_{2} \mathrm{O}\right) \delta 7.87(\mathrm{~d}, J=7.5 \mathrm{~Hz}, 1 \mathrm{H}), 7.77(\mathrm{~d}, J=49.4 \mathrm{~Hz}, 2 \mathrm{H}), 7.62$ $7.55(\mathrm{~m}, 1 \mathrm{H}), 7.07(\mathrm{~d}, J=42.9 \mathrm{~Hz}, 2 \mathrm{H}), 6.88-6.78(\mathrm{~m}, 2 \mathrm{H}), 6.75(\mathrm{~d}, J=7.5 \mathrm{~Hz}, 1 \mathrm{H})$, $3.75-3.38(\mathrm{~m}, 298 \mathrm{H}), 3.08(\mathrm{~s}, 3 \mathrm{H}), 2.61(\mathrm{~s}, 3 \mathrm{H}), 1.36-0.97(\mathrm{~m}, 9 \mathrm{H}) \mathrm{ppm}$.

Zeta Potential Measurements. The zeta potential was determined by means of electrophoretic light scattering (ELS). ELS measurements were performed using a samples were analyzed at $25^{\circ} \mathrm{C}$ and measured in PBS. 


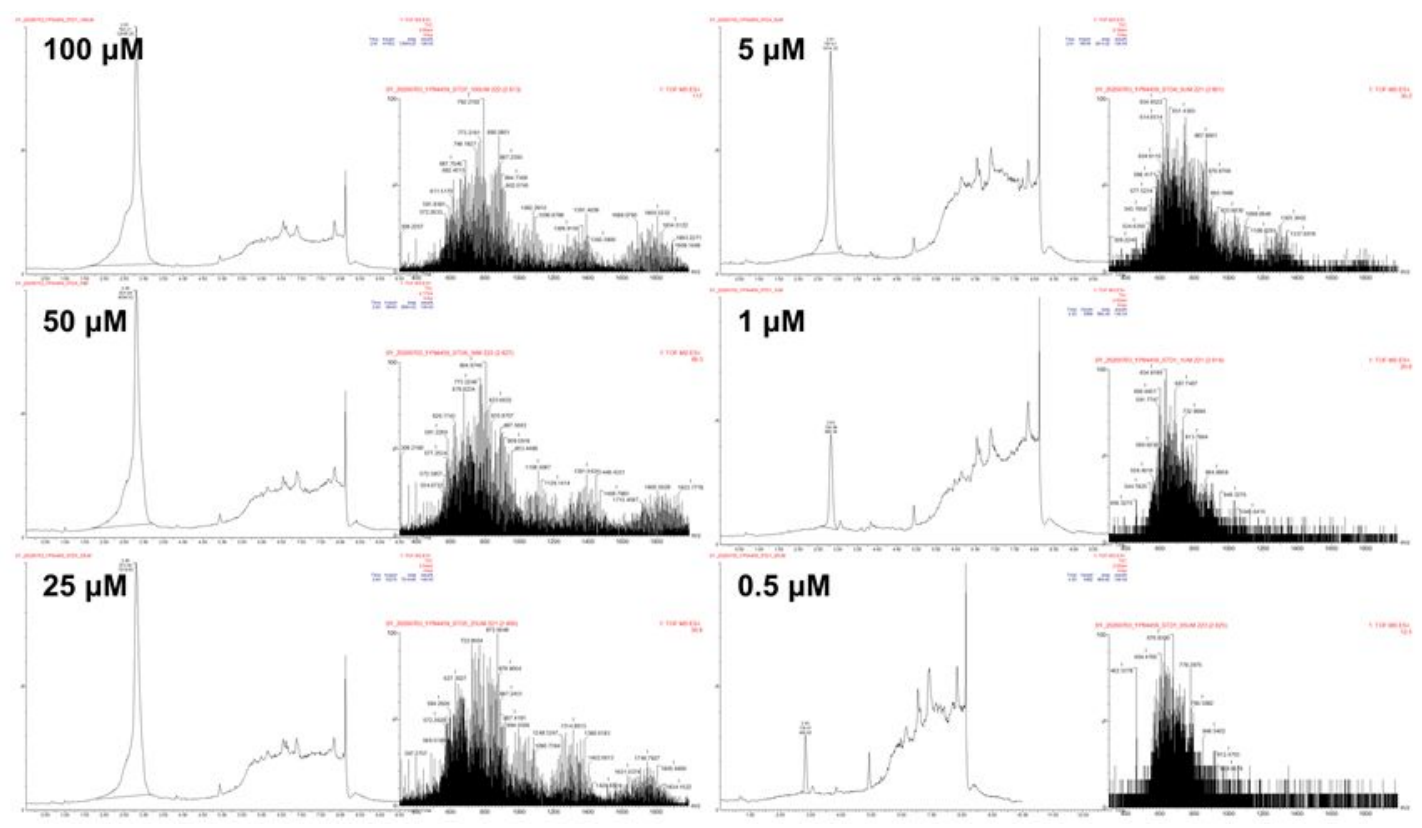

53 Figure S1. Construction method of fitting curves of PEG.
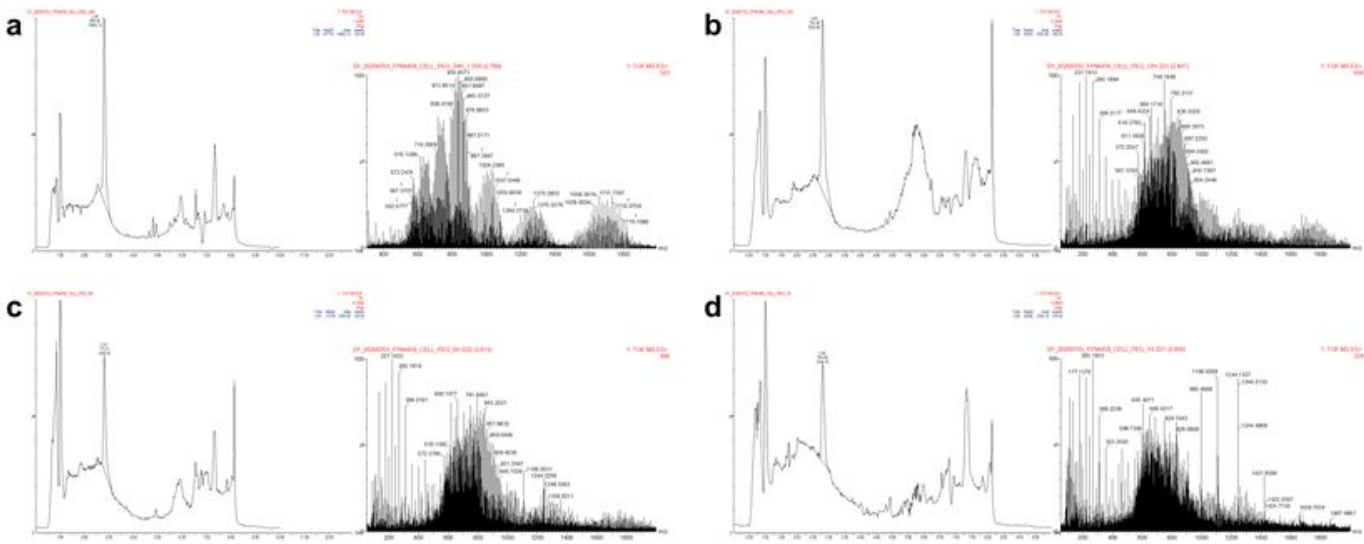

54

55 Figure S2. Content of PEG in BRL 3A cells treated with PEG (5 mM) for different 56 time. a) $24 \mathrm{~h}, \mathrm{~b}) 12 \mathrm{~h}, \mathrm{c}) 6 \mathrm{~h}$ and d) $1 \mathrm{~h}$. 

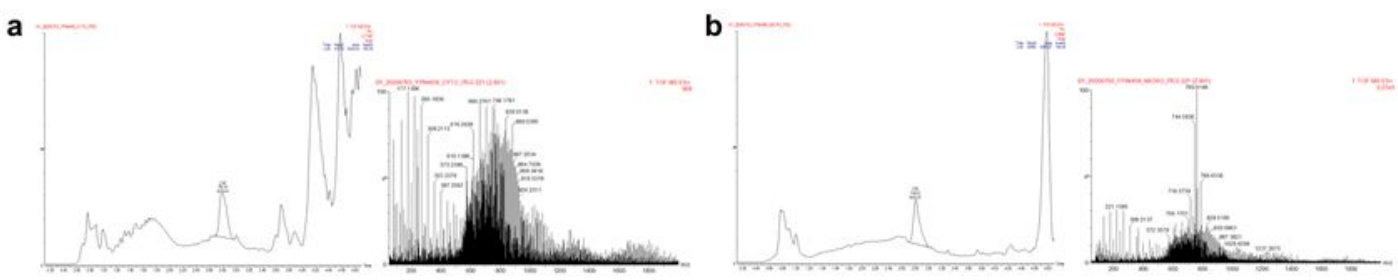

c

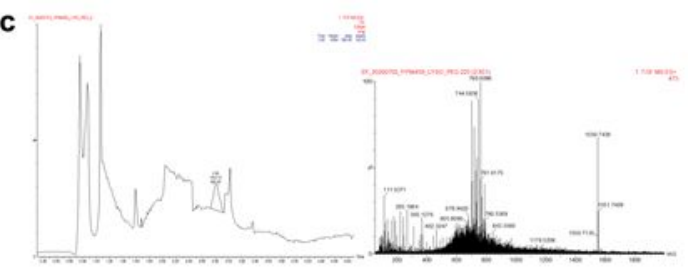

d

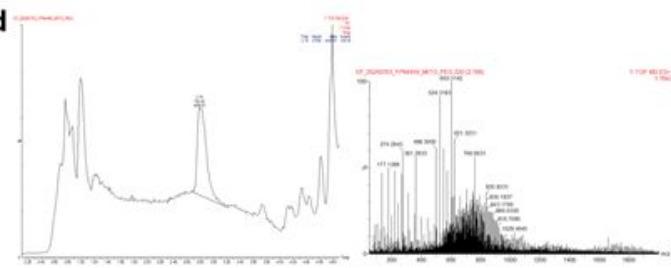

57

58 Figure S3. Detection of PEG in different cellular compartments after BRL 3A cells treated with $5 \mathrm{mM}$ PEG for $24 \mathrm{~h}$. a) cytosol, b) microsome c) lysosome and d) mitochondria of BRL 3A cells treated with PEG 5K (5 mM) for $24 \mathrm{~h}$.

61

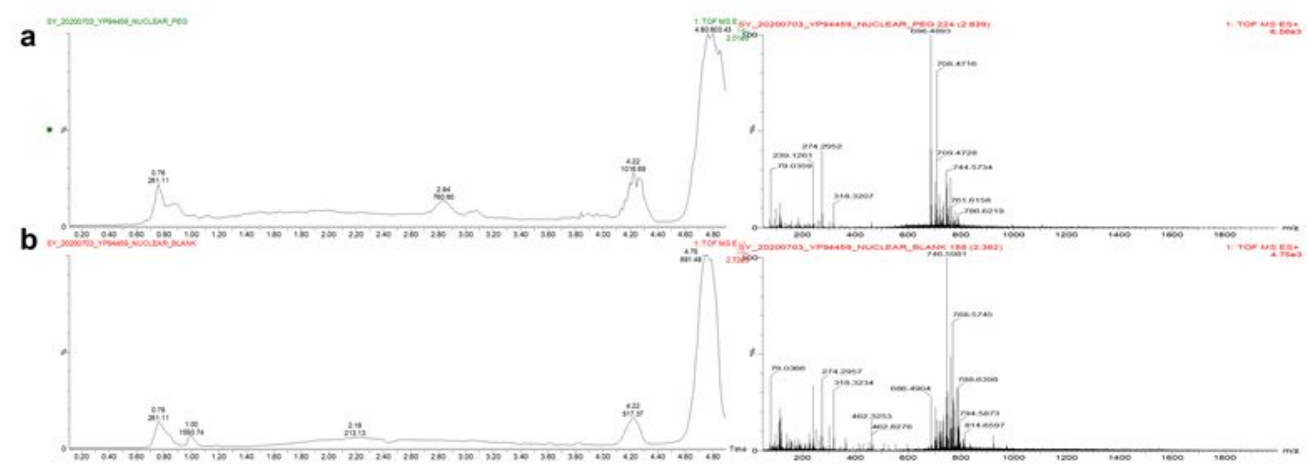

62 Figure S4. Detection of PEG in nucleus of BRL 3A cells treated with PEG (5 mM) for $24 \mathrm{~h}$. a) nucleus, b) blank of BRL 3A cells treated with PEG 5K (5 mM) for $24 \mathrm{~h}$. 


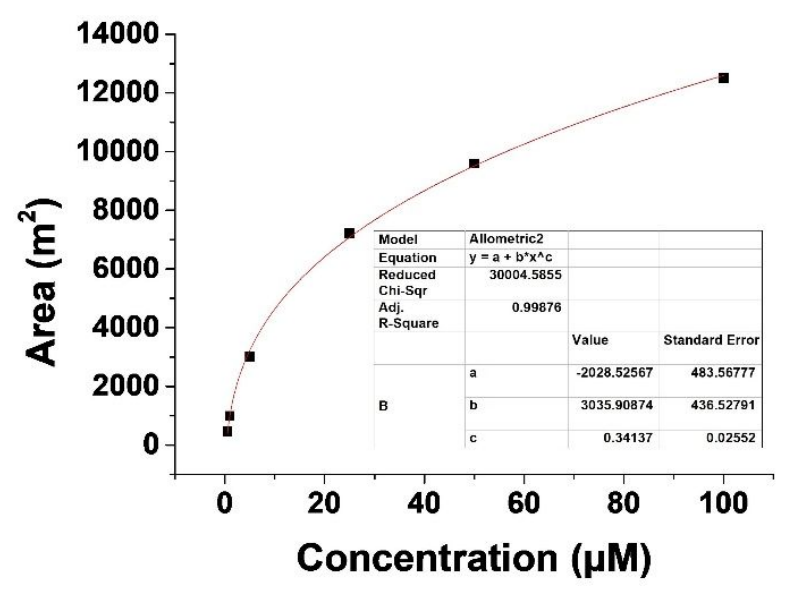

65 Figure S5. Fitting curve constructed by a series of concentrations of purified PEG.

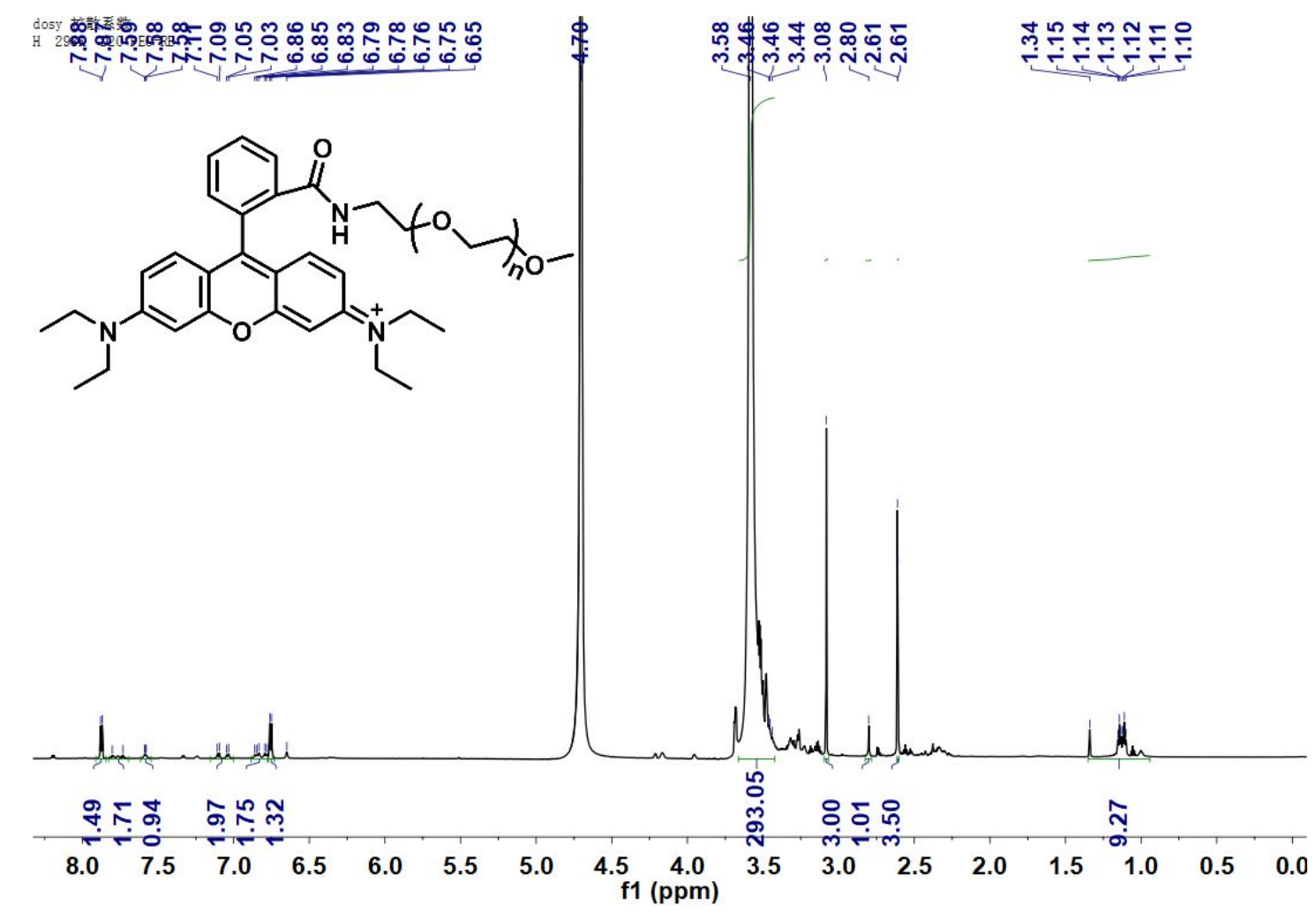

67 Figure S6. ${ }^{1} \mathrm{H}$ NMR spectrum of PEG-RB in $\mathrm{D}_{2} \mathrm{O}(700 \mathrm{MHz})$. 


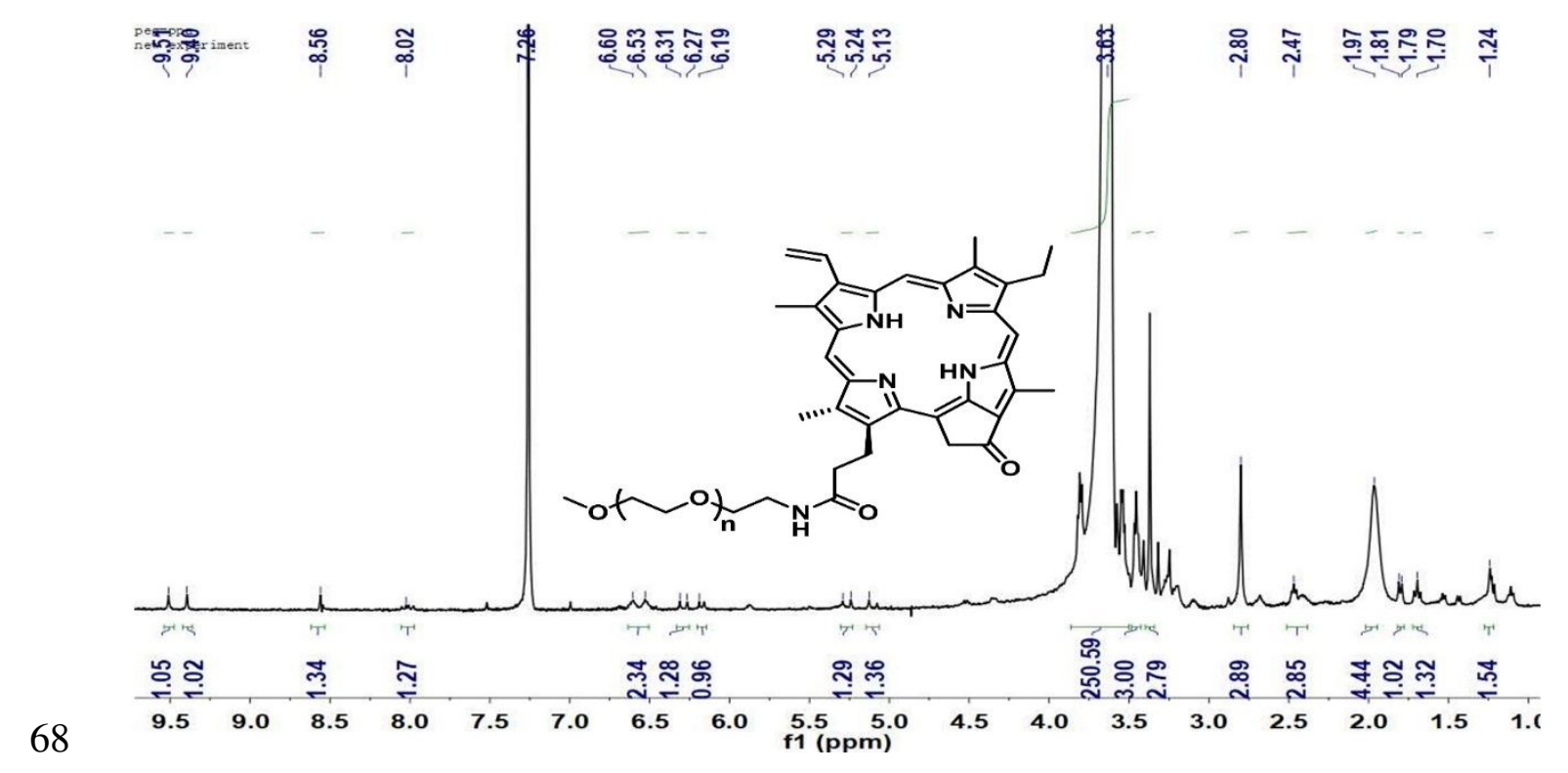

69 Figure S7. ${ }^{1} \mathrm{H}$ NMR spectrum of PEG-PPa in $\mathrm{CDCl}_{3}(400 \mathrm{MHz})$.
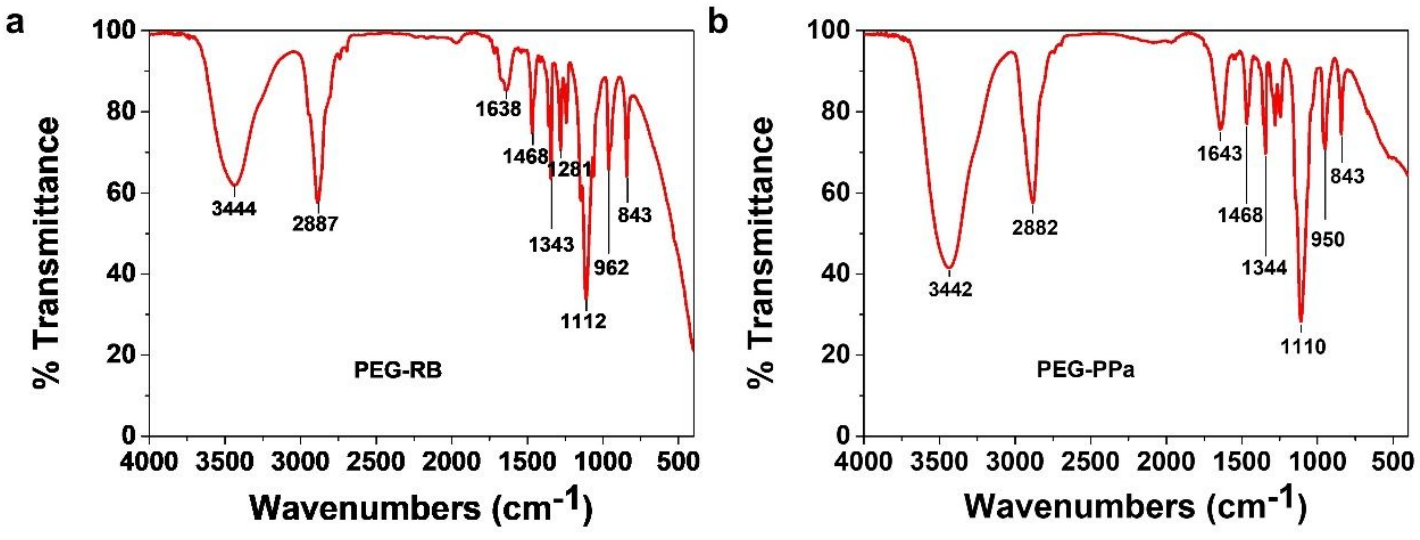

71 Figure S8. The IR spectra of a) PEG-RB and b) PEG-PPa 
a

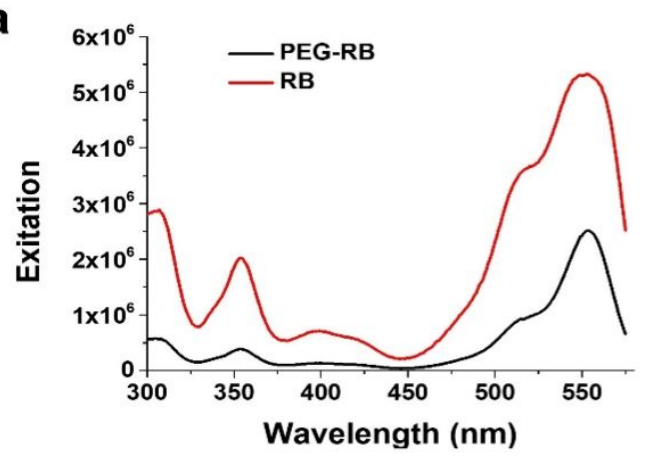

C

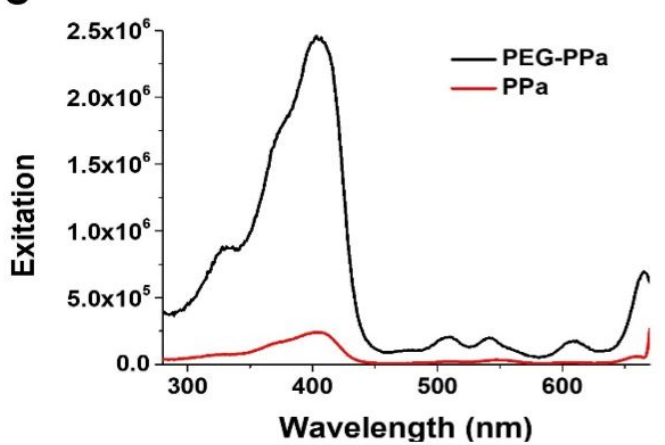

b

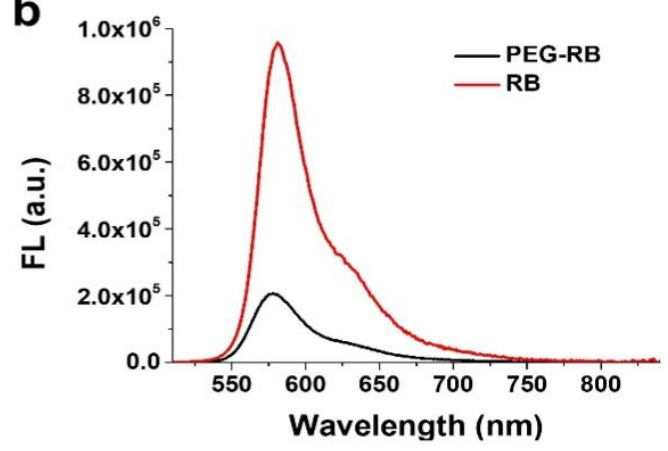

d

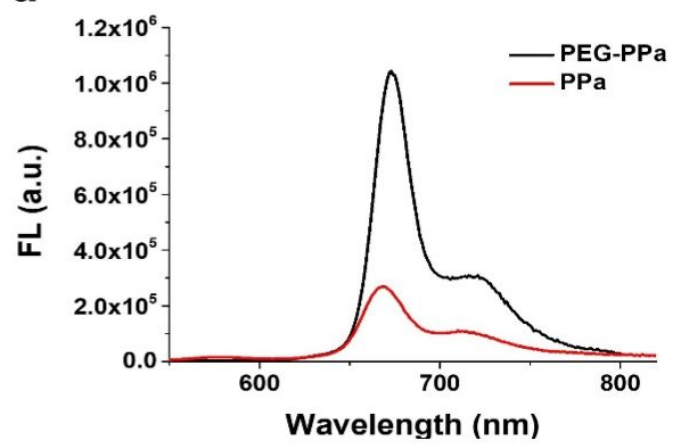

73 Figure S9. Detection of optical properties. a) Fluorescent excitation spectra of PEG-RB

74 and RB. b) Fluorescent emission spectra of PEG-RB and RB. c) Fluorescent excitation

75 spectra of PEG-PPa and PPa. d) Fluorescent emission spectra of PEG-PPa and PPa. 

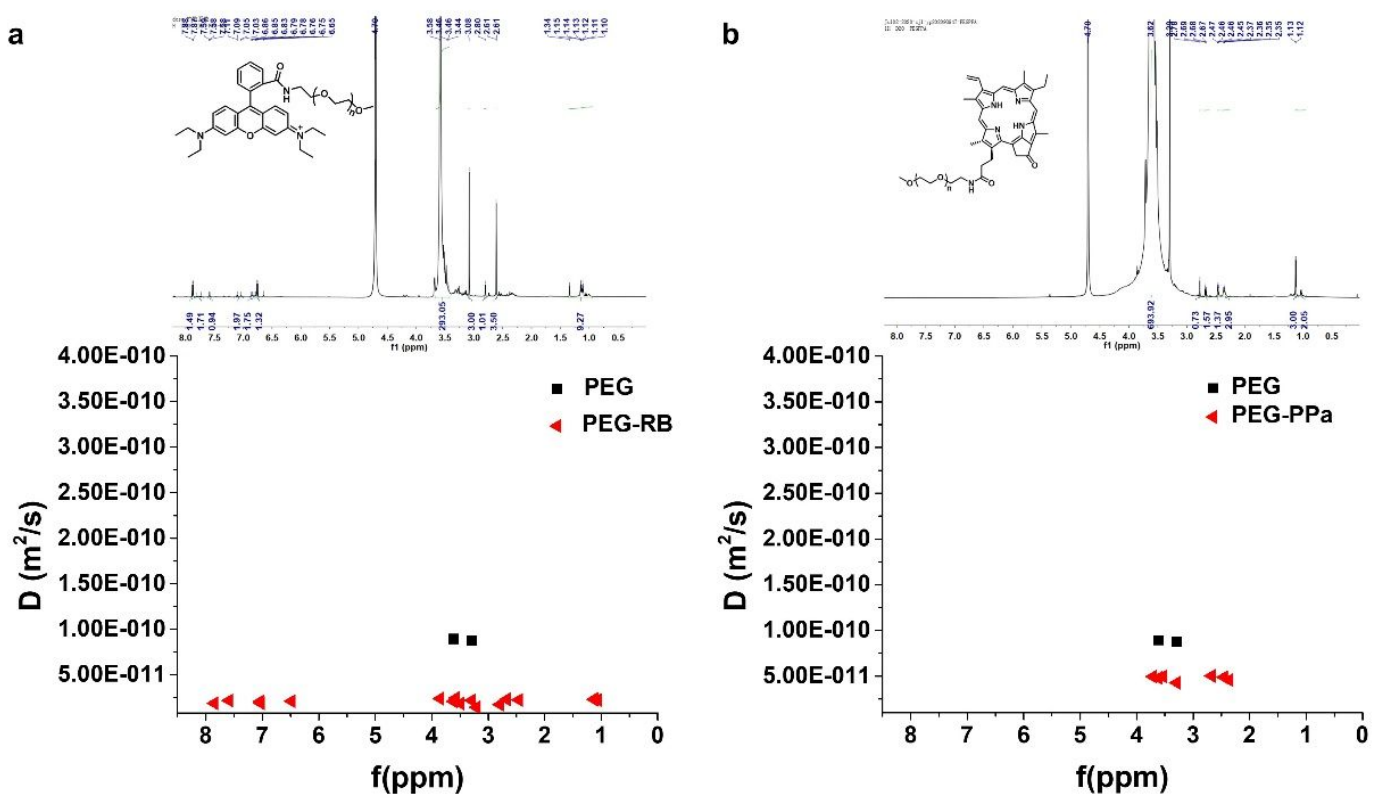

78 Figure S10. DOSY spectra of a) PEG-RB and b) PEG-PPa in $\mathrm{D}_{2} \mathrm{O}(600 \mathrm{MHz})$.
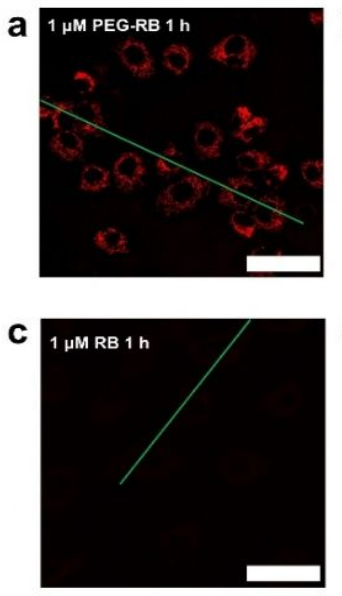

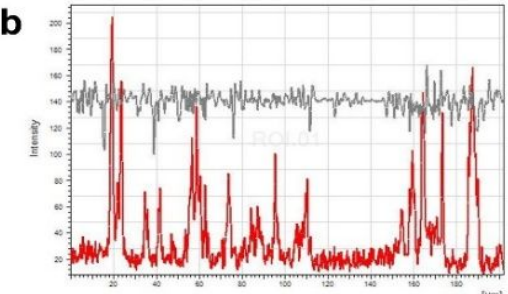

d

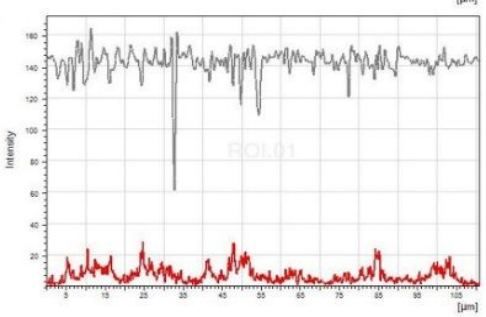

e

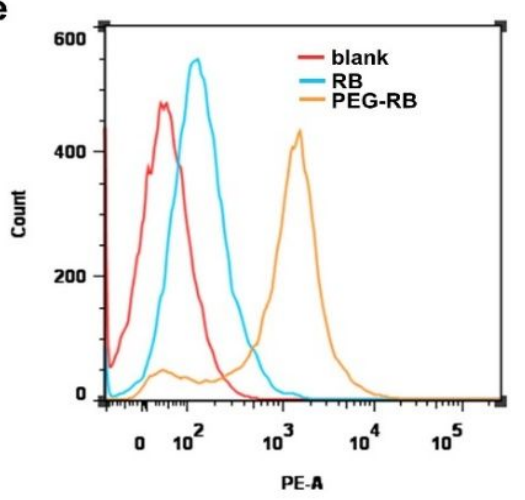

Figure S11. Comparison between PEG-RB and RB on cellular uptake and distribution.

a, c) Confocal images of BRL 3A cells treated with a) PEG-RB and c) RB with same concentration $(1 \mu \mathrm{M})$ for $1 \mathrm{~h} . \mathbf{b}, \mathbf{d})$ fluorescence intensity (red line) of each point on the green line in picture a) and picture c). e) Flow cytometric analyses of BRL 3A cells after incubation with PEG-RB $(10 \mu \mathrm{M})$ and $\mathrm{RB}(10 \mu \mathrm{M})$ for $1 \mathrm{~h}$. Scale bar: $50 \mu \mathrm{m}$. 

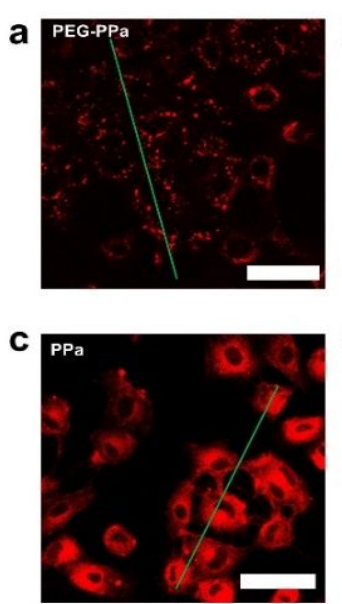
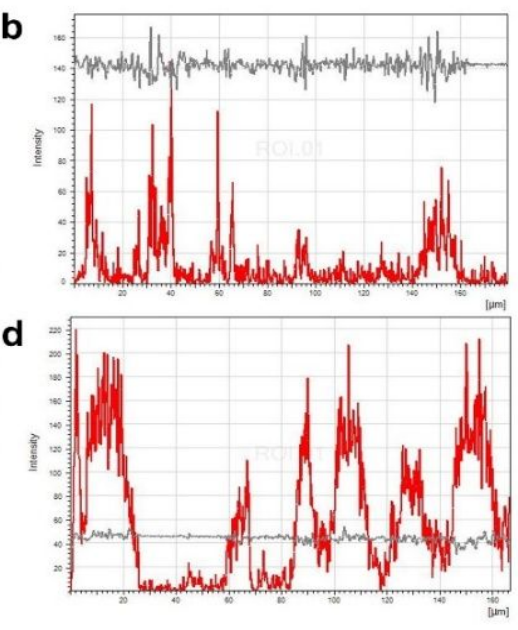

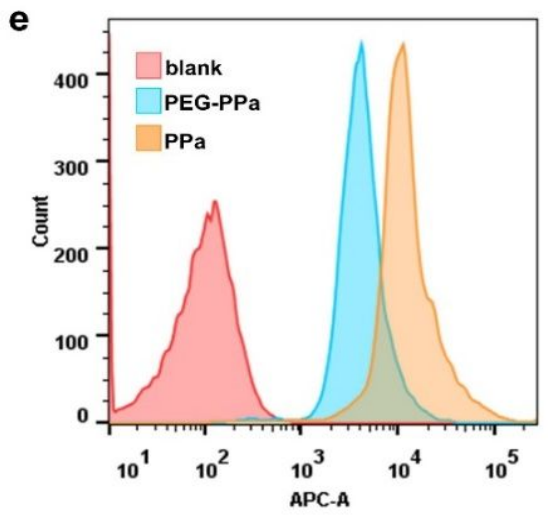

86 Figure S12. Comparison between PEG-PPa and PPa on cellular uptake and distribution.

87 a, c) Confocal images of BRL 3A cells treated with a) PEG-PPa and c) PPa with same

88 concentration $(10 \mu \mathrm{M})$ for $6 \mathrm{~h}$. b, d) Fluorescence intensity (red line) of each point on

89 the green line in picture a) and picture c). e) Flow cytometric analyses of BRL 3A cells

90 after incubation with PEG-PPa $(10 \mu \mathrm{M})$ and PPa $(10 \mu \mathrm{M})$ for $6 \mathrm{~h}$. Scale bar: $50 \mu \mathrm{m}$.
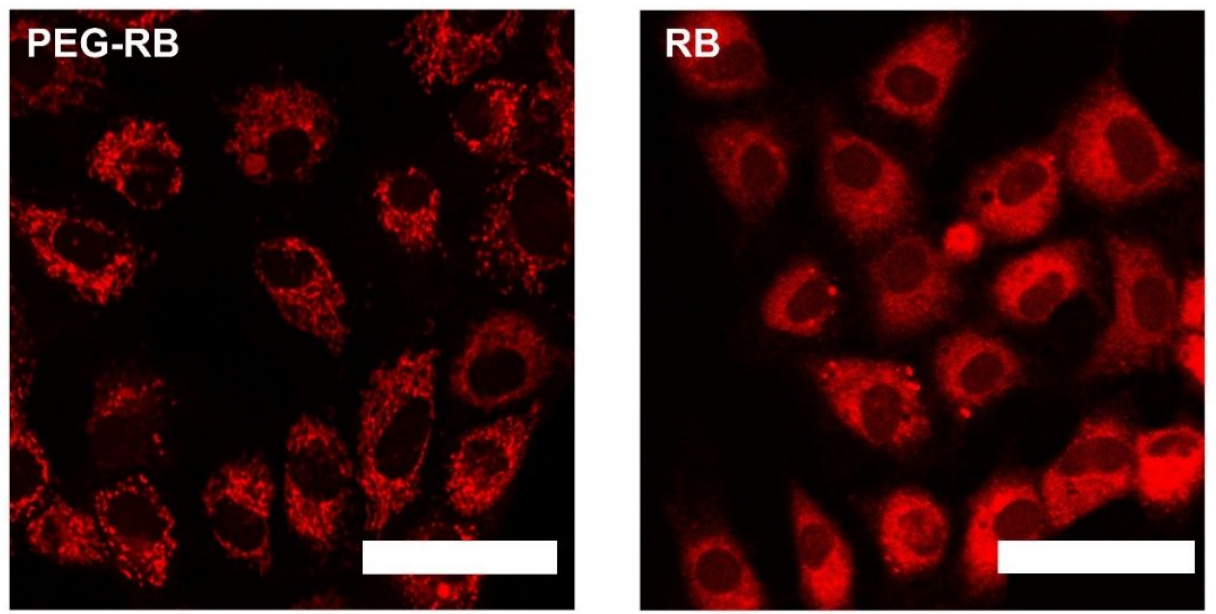

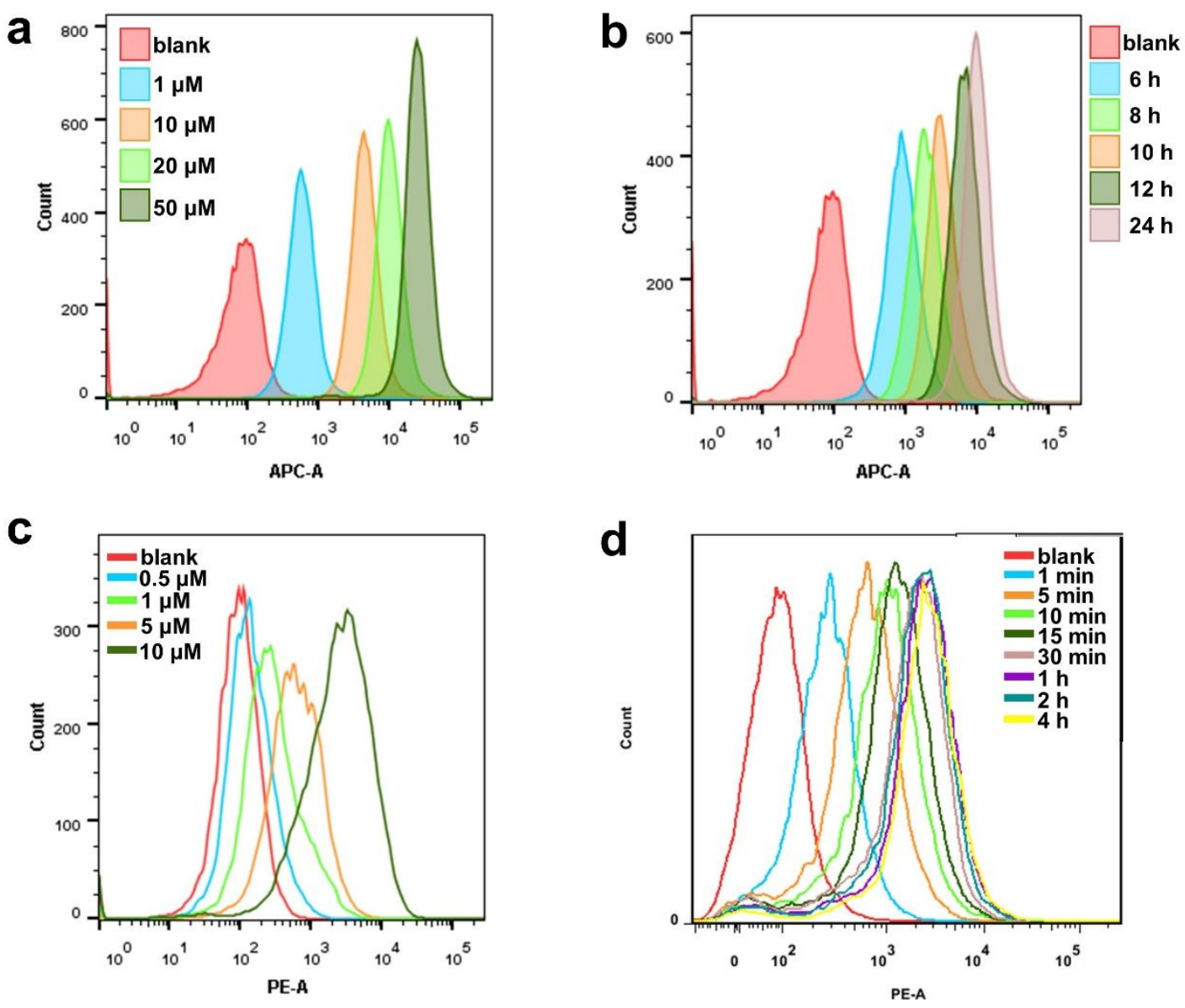

95

Figure S14. Cellular uptake of PEGylated molecules in BRL 3A cells measured by flow

97 cytometry. a) Uptake of PEG-PPa in BRL 3A cells incubated with different

98 concentrations for 6 h. b) Uptake of PEG-PPa $(10 \mu \mathrm{M})$ incubated for different time. c)

99 Uptake of PEG-RB in BRL 3A cells incubated for $2 \mathrm{~h}$ with different concentration. d)

100 Uptake of PEG-RB $(10 \mu \mathrm{M})$ in BRL 3A cells incubated for different time. 

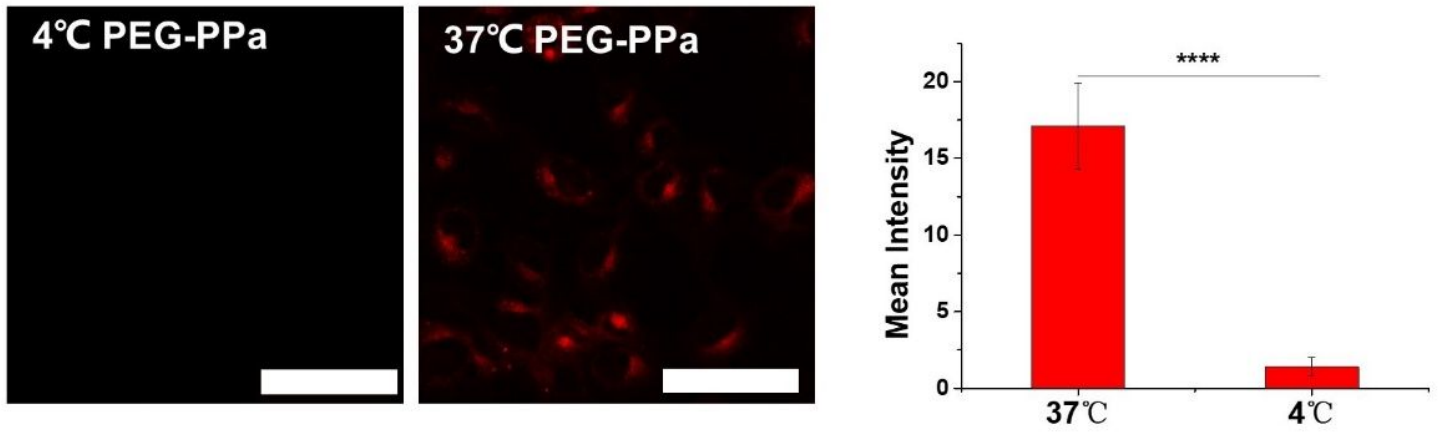

103

104 Figure S15. Confocal images of BRL 3A cells pre-treated at $4{ }^{\circ} \mathrm{C}$ for $30 \mathrm{~min}$, then

105 incubated with PEG-PPa $(100 \mu \mathrm{M})$ under $4{ }^{\circ} \mathrm{C}$ or $37^{\circ} \mathrm{C}$ for another $30 \mathrm{~min}$. The mean

106 fluorescence intensity of these images is calculated by Image J. Scale bar: $50 \mu \mathrm{m}$.

107 $* * * * \mathrm{p}<0.0001$ 

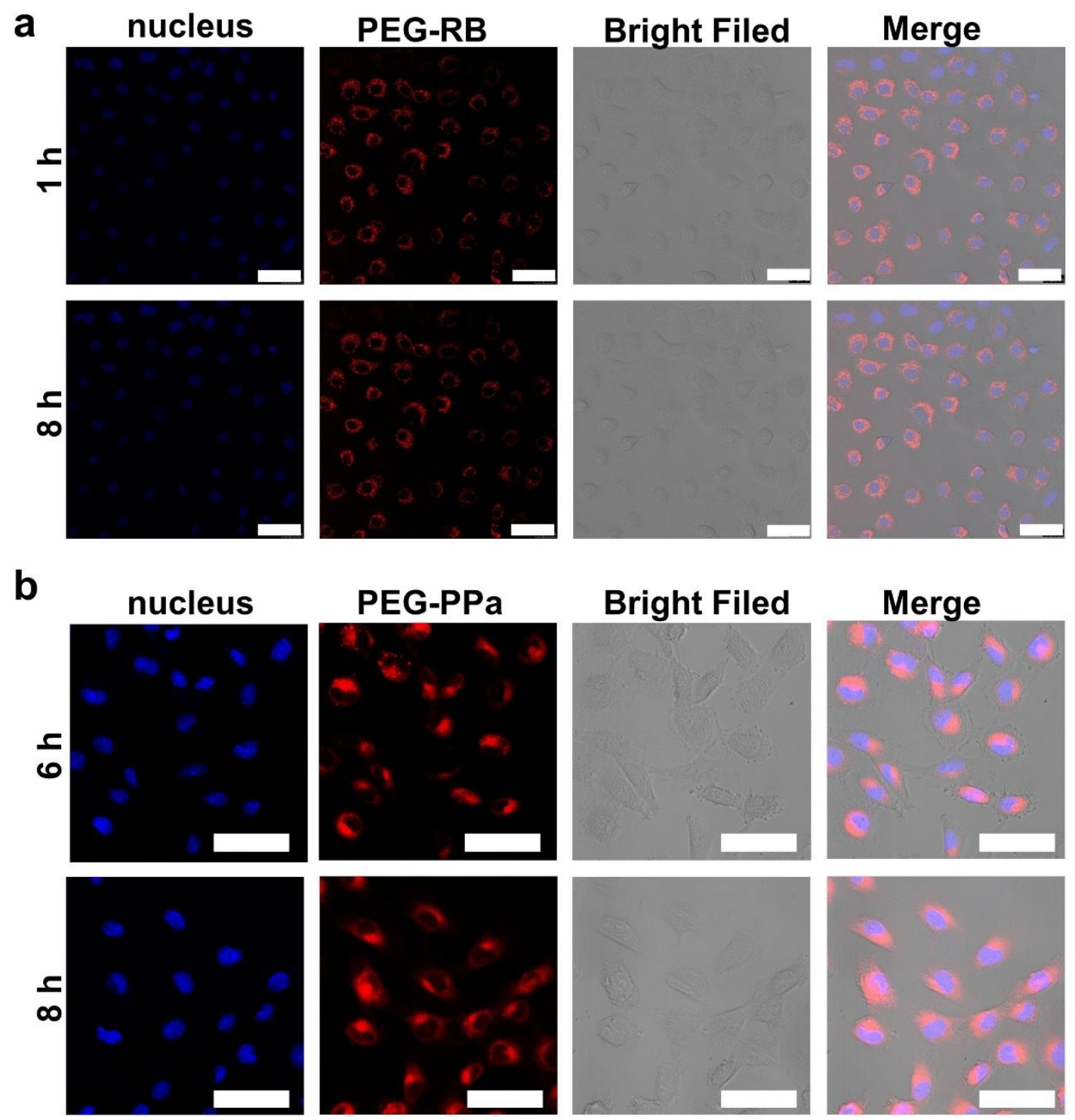

109 Figure S16. Colocalization images of BRL 3A cells pre-treated with a) PEG-RB and b)

110 PEG-PPa for specific duration time and co-staining with Hoechst 33342 (nucleus).

111 Scale bar: $50 \mu \mathrm{m}$ 


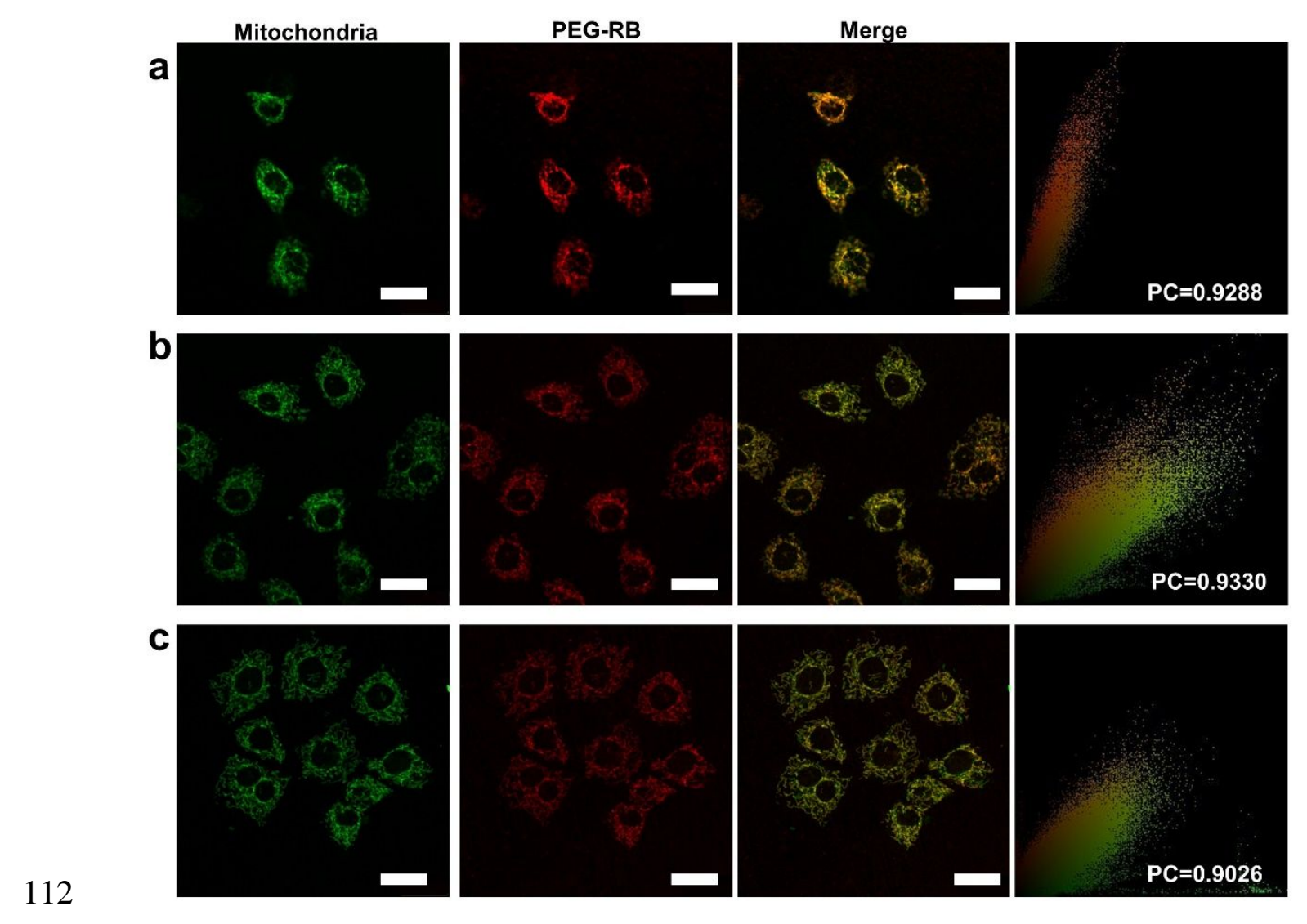

113 Figure S17. Colocalization images of BRL 3A cells. cells pre-incubated with PEG-RB

$114(10 \mu \mathrm{M})$ for $1 \mathrm{~h}$, followed by washed with PBS and incubated in the fresh medium for

115 different time separately and co-staining with mitochondria. a) $24 \mathrm{~h}$, b) $48 \mathrm{~h}$, c) $72 \mathrm{~h}$.

116 PC, Pearson's correlation coefficient. Scale bar: $25 \mu \mathrm{m}$. 

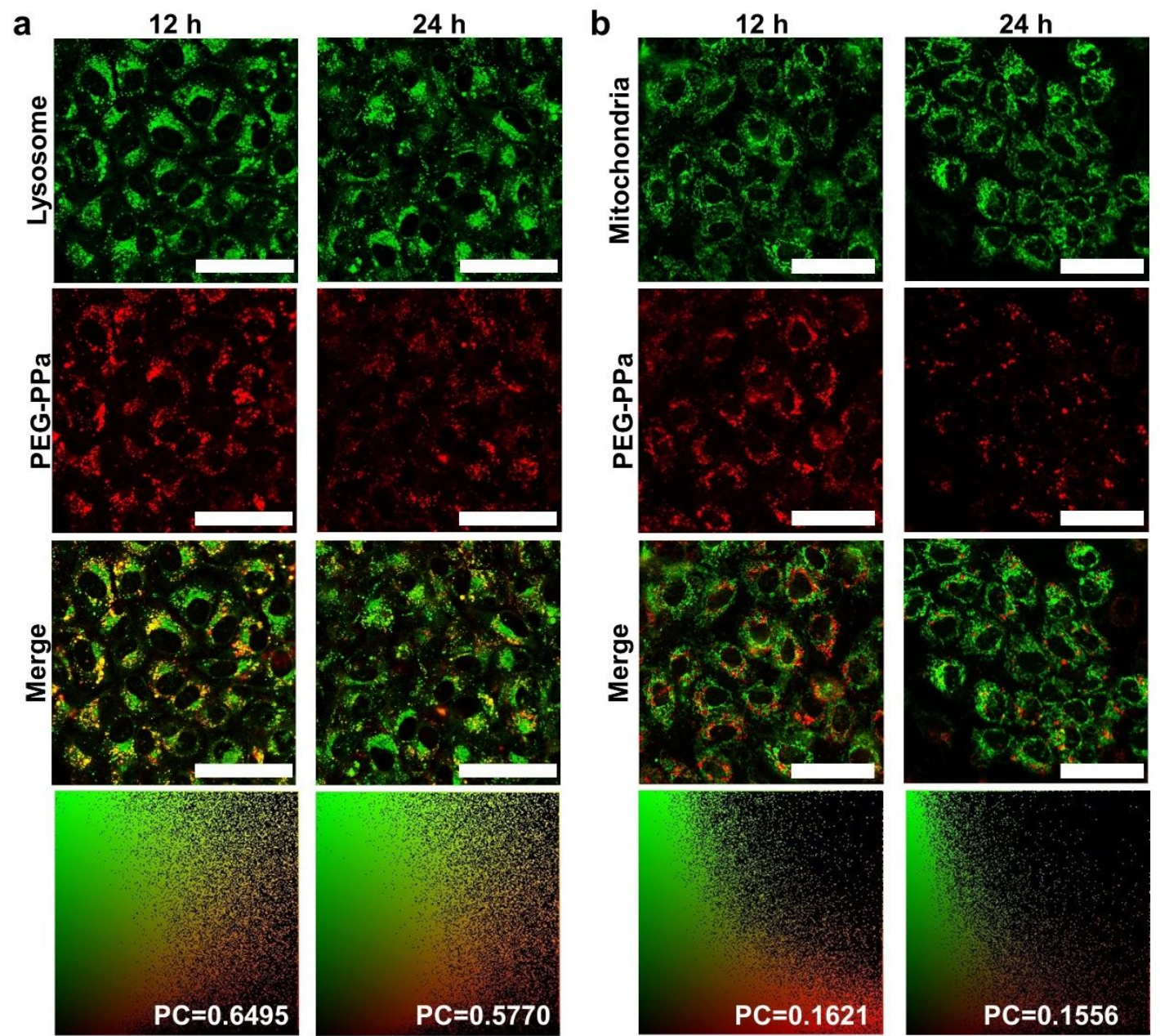

118 Figure S18. Colocalization images of BRL 3A cells pre-incubated with PEG-PPa (10

$119 \mu \mathrm{M}$ ) for $24 \mathrm{~h}$, followed by washed with PBS and incubated in the fresh medium without

120 PEG-RB for another $12 \mathrm{~h}$ and $24 \mathrm{~h}$ respectively and co-staining with a) lysosomes, $\mathrm{b}$ )

121 mitochondria. PC, Pearson's correlation coefficient. Scale bar: $50 \mu \mathrm{m}$. 


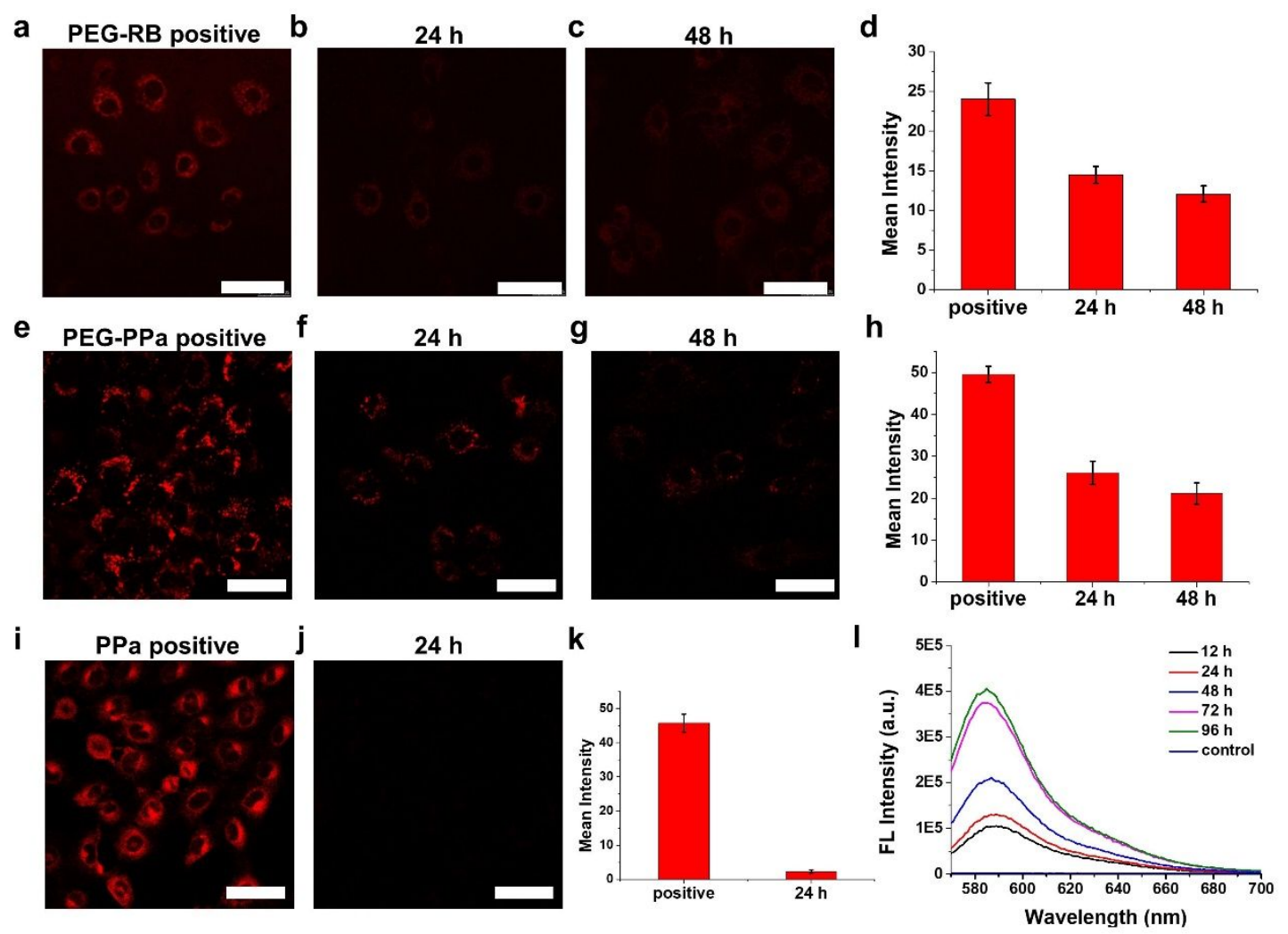

123 Figure S19. Cellular exocytosis of PEG-RB, RB, PEG-PPa and PPa. a-c) Confocal

124 images of BRL 3A cells pre-treated with PEG-RB $(1 \mu \mathrm{M})$ for a) $1 \mathrm{~h}$ as positive control,

125 followed by incubated with fresh medium without PEG-RB for another b) $24 \mathrm{~h}$ and c)

12648 h, respectively. $\mathbf{d}, \mathbf{h}, \mathbf{k})$ Mean intensity fluorescence of internalized d) PEG-RB, h)

127 PEG-PPa and $\mathbf{k}$ ) PPa taken by confocal images. The intensity of fluorescence was

128 measured by Image J. e-g) Confocal images of BRL 3A cells pre-treated with PEG-PPa

$129(10 \mu \mathrm{M})$ for $24 \mathrm{~h}$ as e) positive control, followed by incubated with fresh medium

130 without PEG-PPa for another f) $24 \mathrm{~h}$ and g) $48 \mathrm{~h}$, respectively. $\mathbf{i}, \mathbf{j}$ ) Confocal images of

131 BRL 3A cells pre-treated with $\mathrm{PPa}(10 \mu \mathrm{M})$ for e) $24 \mathrm{~h}$ as positive control, followed by

132 incubated with fresh medium without PPa for another f) $24 \mathrm{~h}$. 1) Fluorescent intensity 
133 spectrum of exocytose PEG-RB in BRL 3A cells. BRL 3A cells were pre-treated with

134 PEG-RB $(50 \mu \mathrm{M})$ for $2 \mathrm{~h}$, followed by washing with PBS, adding fresh medium and

135 incubating for specific period separately and collecting the supernatant to detect their

136 fluorescence intensity separately. The mean fluorescence intensity of these images is

137 calculated by Image J. Scale bar: $50 \mu \mathrm{m}$.
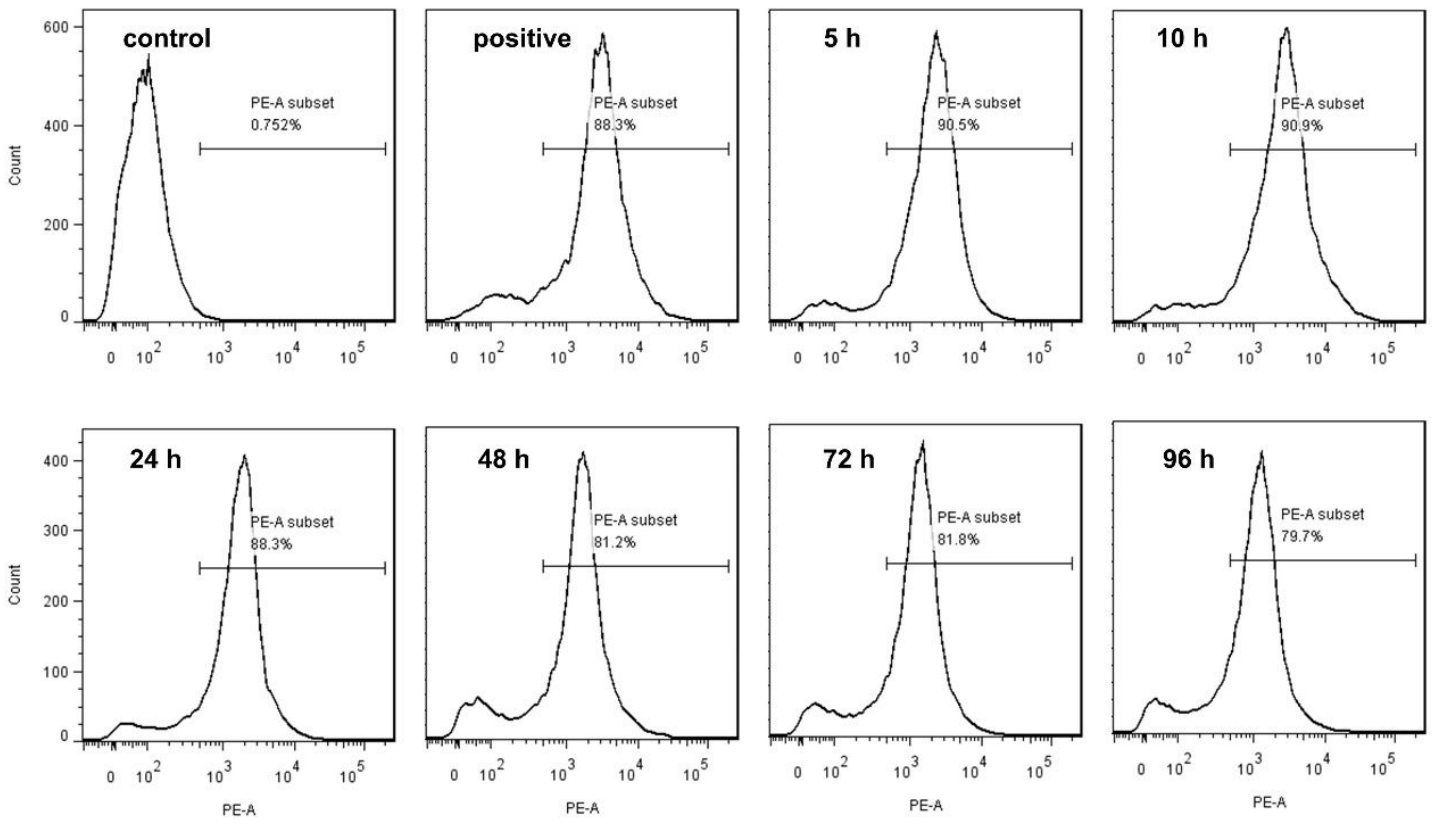

138

139 Figure S20. Cellular exocytosis of PEG-RB analyzed by flow cytometry, showing the rate of cells with PEG-RB for different incubation time. 

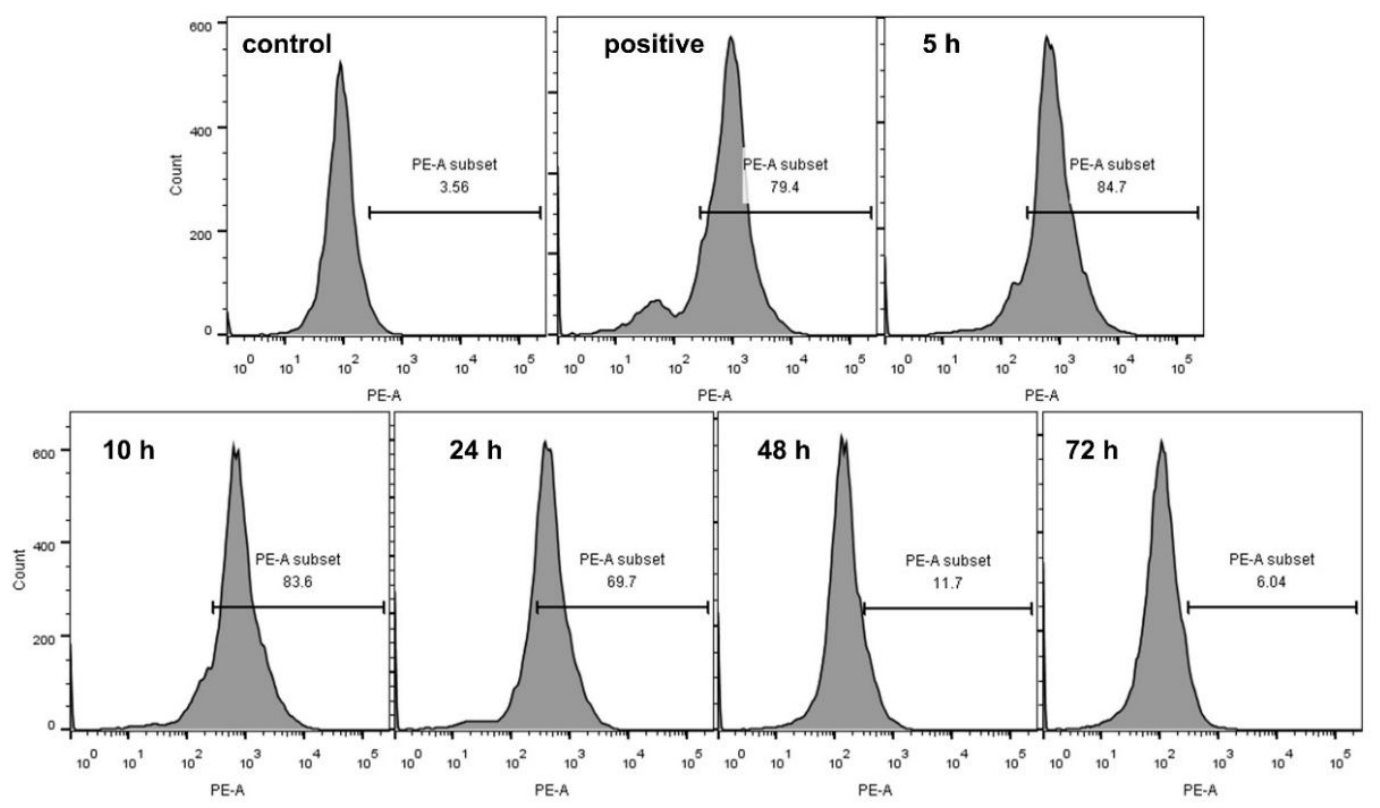

142 Figure S21. Cellular exocytosis of RB analyzed by flow cytometry, showing the rate of

143 cells with RB for different incubation time.
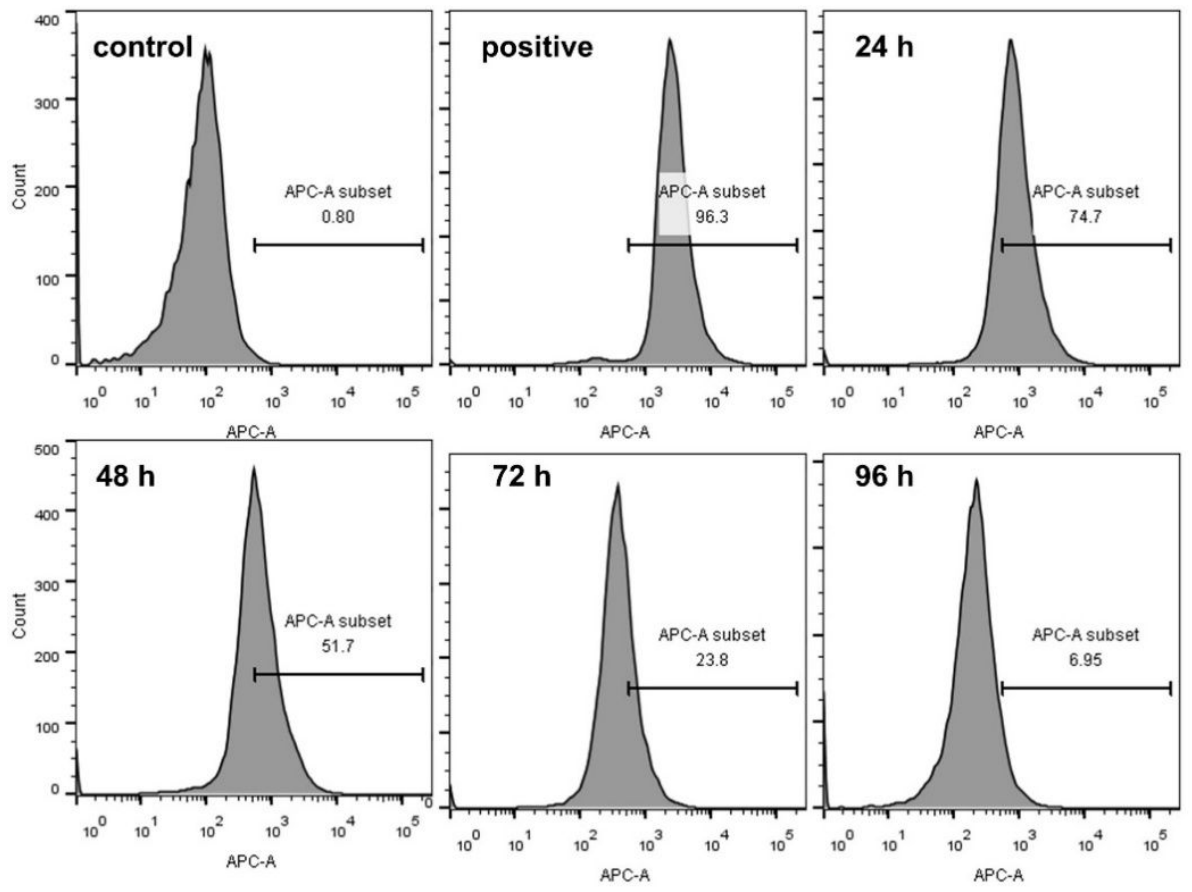

144 
145 Figure S22. Cellular exocytosis of PEG-PPa analyzed by flow cytometry, showing the 146 rate of cells with PEG-PPa for different incubation time.

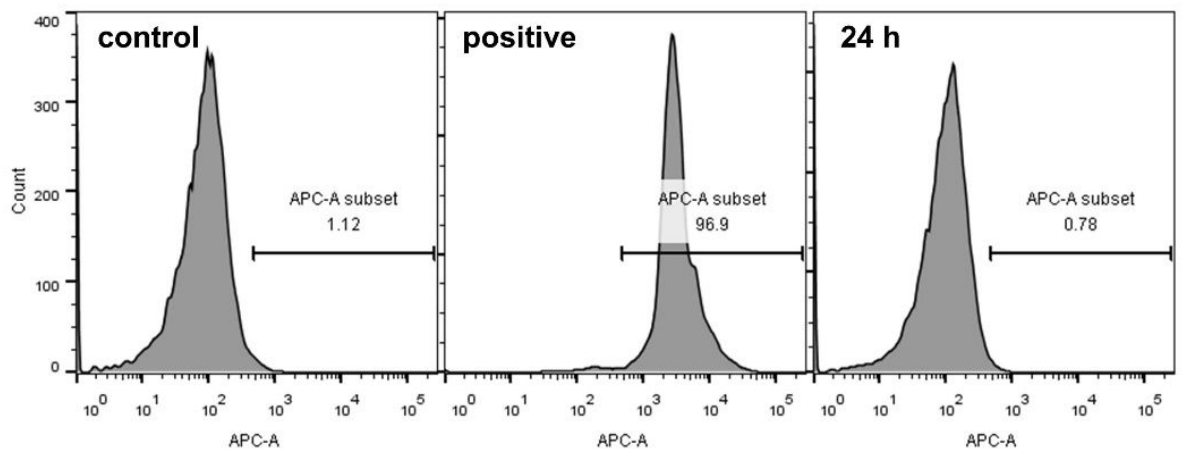

148 Figure S23. Cellular exocytosis of PPa analyzed by flow cytometry, showing the rate

149 of cells with PPa for different incubation time. 